\title{
Peningkatan Kapasitas Usaha Pada PKM Usaha Olahan Pisang di Kabupaten Bombana
}

\author{
Gusti R. Sadimantara ${ }^{1}$ dan Sitti Leomo ${ }^{2 *}$ \\ 1)Jurusan Agroteknologi, Fakultas Pertanian, Universitas Halu Oleo, Kendari, Sulawesi Tenggara, Indonesai \\ ${ }^{2)}$ Jurusan Ilmu Tanah, Fakultas Pertanian, Universitas Halu Oleo, Kendari, Sulawesi Tenggara, Indonesai
}

\section{Article history}

Received: 15 Maret 2020

Revised: 25 Maret 2020

Accepted: 11 Mei 2020

*Corresponding Author:

Sitti Leomo

Jurusan Ilmu Tanah, Fakultas Pertanian, Universitas Halu Oleo, Kendari, Sulawesi

Tenggara, Indonesai;

Email: sittileomo@yahoo.com

\begin{abstract}
Bananas are tropical fruit commodities that are very popular and have a high potential to be managed intensively and agribusiness oriented. Banana plants have many benefits for human needs so that they have high economic value. Bananas can play a role as food substitutes containing calories, protein, carbohydrates, fats, vitamins, and minerals that are needed by the human body. The potential development of bananas is quite significant because it has broad adaptability to various agro-climate zones and has excellent potential for commercial growth as an export commodity. The market potential abroad is enormous and continues to increase. The domestic market's potential also increased due to rising levels of income and quality of life. There are many obstacles to increasing domestic banana production. Besides, processed banana products have not optimally produced as a source of livelihood and community income. This PKM partner business group has prospective business potential to be developed, because the banana and processed banana-based market is enormous, both at local and national levels. The banana production business that has developed has not been economically productive due to various limitations and constraints on land availability. In such conditions, bananas have cultivated as inserted plants. However, these two farmer groups have the potential to be productive farmer groups. The introduction of shade-tolerant bananas can be a solution for increasing banana production on limited land through the intercropping system. While the introduction of improvements to the processing and packaging system of Dempok bananas can improve the added value and quality of the products produced.
\end{abstract}

Keywords: Banana; shade toleran; PKM; dempok

Abtrak: Pisang merupakan komoditas buah tropis yang sangat populer dan mempunyai potensi cukup tinggi untuk dikelola secara intensif dan berorientasi agribisnis. Tanaman pisang memiliki banyak manfaat untuk keperluan manusia sehingga memiliki nilai ekonomi tinggi. Pisang dapat berperan sebagai bahan pangan substitusi yang mengandung kalori, protein, karbohidrat, lemak, vitamin dan mineral yang sangat dibutuhkan oleh tubuh manusia. Potensi pengembangan pisang cukup besar karena memiliki daya adaptasi yang luas terhadap berbagai zone agroklimat, serta memiliki potensi besar untuk dikembangkan secara komersial sebagai salah satu komoditas ekspor. Potensi pasarnya di luar negeri sangat besar dan senantiasa meningkat namun belum dapat sepenuhnya termanfaatkan. Sementara potensi pasar dalam negeri juga meningkat akibat naiknya tingkat pendapatan dan kualitas hidup masyarakat serta variasi berbagai pengolahan pisang. Meskipun demikian peningkatan produksi pisang dalam negeri banyak mengalami kendala, selain karena belum diterapkannya teknik budidaya sesuai anjuran, adanya serangan hama dan penyakit 
juga terbatasnya lahan yang dapat digunakan untuk peningkatan produksi pisang. Selain itu produk olahan pisang belum diusahakan secara maksimal sebagai sumber penghidupan dan pendapatan masyarakat. Mitra kelompok usaha mitra PKM ini memiliki potensi usaha yang prospektif untuk dikembangkan, karena pasar pisang dan olahan berbasis pisang sangat besar, baik di tingkat lokal maupun nasional. Usaha produksi pisang yang dikembangkan belum produktif secara ekonomis, akibat berbagai keterbatasan dan kendala yang dimiliki, terutama dalam budidaya, produksi dan pemasaran produk buah-buahan. Dari segi produksi, keterbatasan produksi terjadi karena keterbatasan lahan. Hal ini disebabkan karena lahan utama yang mereka miliki telah digunakan untuk pengembangan komoditas lain seperti kakao atau kelapa. Pada kondisi demikian, pisang hanya diusahakan sebagai tanaman sisipan. Namun kedua kelompok tani ini dapat ditingkatkan menjadi kelompok tani yang produktif. Introduksi pisang kate yang toleran naungan dapat menjadi solusi untuk peningkatan produksi pisang pada lahan terbatas melalui pola usaha tumpang sari atau agroforestri. Sementara introduksi perbaikan system pengolahan dan pengemasan pisang dempok dapat meningkatkan nilai tambah dan mutu produk yang dihasilkan.

Kata kunci: Pisang; shade toleran; PKM; dempok.

\section{PENDAHULUAN}

Pisang merupakan komoditas buah tropis yang sangat populer dan mempunyai potensi cukup tinggi untuk dikelola secara intensif dan berorientasi agribisnis (Samson, 1992; Nelson et al., 2006; Aurore et al., 2009). Pisang merupakan buah utama di daerah tropis (Hölscher et al., 2014). Pisang memiliki banyak jenis diantara buah meja dan buah pisang yang harus diolah sendiri (Englberger, 2012; Muhidin, et al. 2015; Muhidin, et al. 2016). Tanaman pisang memiliki banyak manfaat untuk keperluan manusia. Selain buahnya, dari tanaman pisang juga dapat dimanfaatkan bunganya untuk dijadikan sayur, daunnya untuk pembungkus, batangnya untuk tali pengikat, kulitnya untuk pakan ternak, bahkan bonggolnya pun dapat dikonsumsi sebagai sayur (Ekesa et al., 2013a, 2013b). Pisang dapat berperan sebagai bahan pangan substitusi yang mengandung kalori, protein, karbohidrat, lemak (Ekesa et a., 2013; Kumar et al., 2013; Eleazu dan Nwosu, 2015; Kementan, 2015), vitamin dan mineral yang sangat dibutuhkan oleh tubuh manusia (Balitbangtan, 2008).

Potensi pengembangan pisang cukup besar karena memiliki daya adaptasi yang luas terhadap berbagai zone agroklimat, serta memiliki potensi besar untuk dikembangkan secara komersial sebagai salah satu komoditas ekspor. Potensi pasarnya di luar negeri sangat besar dan senantiasa meningkat namun belum dapat sepenuhnya termanfaatkan. Sementara potensi pasar dalam negeri juga meningkat akibat naiknya tingkat pendapatan dan kualitas hidup masyarakat serta variasi berbagai pengolahan pisang.

Indonesia merupakan produsen pisang nomor enam di dunia diantara 20 banana Negara penghasil pisang. Produksi pisang Indonesia rata-rata mencapai 5.36 juta ton, dengan sentra produksi utama berada di Pulau Jawa dan Sumatera. Kemudian produksinya meningkat mencapai 5.454.226 ton pada tahun 2007 (BPS, 2010). Dari jumlah produksi tersebut, diperkirakan sebesar 3.0 juta ton diantaranya merupakan jenis pisang meja atau pisang untuk dikonsumsi segar. Apabila diasumsikan sekitar $60 \%$ (150 juta) dari jumlah penduduk Indonesia (250 juta) menyukai pisang, maka besarnya tingkat konsumsi pisang per kapita di Indonesai hanya $20 \mathrm{~kg} / \mathrm{tahun}$ atau $55 \mathrm{gram} / \mathrm{hari}$. Padahal rata-rata berat pisang ambon kuning saja mencapai $75 \mathrm{gram} / \mathrm{buah}$. Ini berarti kemampuan penyediaan buah pisang untuk konsumsi buah meja saja masih sangat kecil dan masih memiliki peluang besar untuk ditingkatkan produksinya. Belum lagi jika ditambah dengan penggunaan pisang dalam berbagai bentuk olahan yang diperkirakan sama besarnya dengan kebutuhan pisang meja.

Oleh karena itu terdapat potensi pasar pisang yang sangat besar dan terbuka di dalam negeri, yang perlu diupayakan pemenuhannya melalui peningkatan produksi. Namun peningkatan produksi pisang dalam negeri banyak mengalami kendala, selain karena belum diterapkannya teknik budidaya sesuai anjuran, adanya serangan hama dan penyakit juga terbatasnya lahan yang dapat digunakan untuk peningkatan produksi pisang. Selain itu produk olahan pisang belum diusahakan secara maksimal sebagai sumber penghidupan dan 
pendapatan masyarakat. Mitra kegiatan PKM adalah Kelompok Tani Buah dan Kelompok Tani Usaha Dempok Pisang di desa Batu Putih Kecamatan Poleang. Kelompok pertama focus pada usaha produksi pisang. Sedangkan kelompok kedua focus pada usaha olahan pisang terutama dempok atau secara umum sering dikenal sebagai sale pisang.

\section{METODE}

Berdasarkan permasalahan yang dihadapi mitra PKM, maka solusi yang ditawarkan adalah sebagai berikut :

1. Integrasi budidaya pisang dengan pola budidaya tanaman tahunan yang ada, melalui introduksi tanaman pisang tipe pendek yang toleran terhadap kondisi intensitas cahaya rendah sehingga dapat ditanam dibawah tegakan tanaman perkebunan. Keadaan ini dapat menjadi jawaban terhadap keterbatasan lahan yang dimiliki. Melalui pola ini petani tidak perlu menyiapkan lahan atau kebun khusus tetapi dapat memanfaatkan lahan-lahan yang ada selama ini, sehingga terjadi peningkatan intensitas usaha pisang.

2. Pengembangan model usaha pisang terintegrasi dalam pola agroforestri dengan tanaman tahunan atau dengan kehutanan, untuk meningkatkan kapasitas produksi pisang.

3. Pengembangan usaha olahan pisang terutama dalam bentuk pisaang dempok atau sale pisang, yang dikemas dengan baik sehingga dapat dipasarkan ke daerah lain dan dapat tahan lama. Introduksi dan perbaikan system pengemasan serta perbaikan teknik pengolahan pisang menjadi pisang dempok atau pisang sale, menjadi jawaban atas permasalahan lemahnya daya siang produk pisang sale yang dihasilkan.

Kegiatan PKM penerapan Ipteks untuk mempercepat aplikasi teknologi dan perbaikan manajemen sistem produksi pisang melalui introduksi pisang kate toleran naungan dan usaha produksi olahan berbasis pisang, akan ini dilakukan melalui penyuluhan, pelatihan, bimbingan teknis prosesing produksi dan pembuatan demplot budidaya pisang terintegrasi dengan usaha produksi pertanian yang telah ada serta serta demplot dan incubator usaha olahan pisang.

\section{HASIL DAN PEMBAHASAN}

\section{Kondisi Eksisting Lokasi Kegiatan}

Kegiatan IbM penerapan Ipteks ini dilakukan di Desa Paria Kecamatan Poleang Tengah Kabupaten Bombana, bertujuan untuk meningkatkan pendapatan petani pisang melalui diversifikasi usaha produksi pisang dan olahnnya menjadi dempo atau pisang sale, sesuai standar pasar, dengan kemasan yang baik. Petani umumnya belum melakukan budidaya tanaman pisang secara memadai sehingga tanaman saling manunagi dengan kapasitas produksi yang rendah.

Kegiatan penerapaan Ipteks ini bertujuan untuk merangsang terjadinya integrasi usaha produksi dan sekaligus dengan pengolahan lebih lanjut pisang menjadi dempo. Melalui kegiatan ini juga diharapkan produksi pisang yang terjadi dapat meningkat sehingga terjadi peningkatan bahan baku pembuatan dempo.

Pengembangan usaha olahan pisang terutama dalam pisang sale atau dempok, akan dihasilkan dempo atau sale pisang yang bermutu standar, yang nantinya akan dikemas lebih lanjut menjadi produk bernilai eknomi tinggi dan higisnis.

Metode yang digunakan untuk penerapan paket teknologi dibagi dalam kegiatan

1. Pra-implementasi, yaitu kegiatan yang dilakukan sebelum introduksi teknologi, berupa (a) sosialisasi, (b) penyuluhan dan (c) pelatihan,

2. Implementasi, yaitu kegiatan saat implementasi dan introduksi teknologi tepat guna, dimulai dari (b) bimbingan teknis, pembenahan kelompok usaha, pembenahan aset paket teknologi, evaluasi proses produksi dan introduksi teknologi produksi pisang yang sehat dan ramah lingkungan.

3. Pasca implementasi, merupakan kegiatan yang dilakukan setelah introduksi teknologi yang meliputi kegiatan pendampingan usaha, promosi dan diseminasi hasil kegiatan. 


\section{Kemajuan Pelaksanaan Kegiatan}

Kemajuan pelaksanaan kegiatan yang telah dilakukan meliputi sosialisasi kepada mitra petani, pemilihan lokasi tempat peragaan demplot dan penyiapan sarana dan prasarana produksi. Kegiatan sosialisasi dan pemilihan mitra kegiatan telah dilakukan sejak awal disetujuinya kegiatan ini. Namun pelaksanaan kegiatan di lapangan disesuaikan dengan terminasi dan waktu pencairan dana.

1. Pemilihan Area Demplot

Lokasi area dipilih berdasarkan kondisi pertanaman, umur tanaman dan tersedianya bidang lahan yang masih diusahakan untuk budidaya pisang. Pemilihan lokasi dilakukan juga pada lokasi yang terletak di pinggir jalan agar kegiatan yang dilakukan terlihat khalayak ramai.

2. Pembuatan Demplot

Kegiatan yang dilkukan pada demplot terpilih antara lain sanitasi dan penyehatan tanaman pisang sebagai tanaman utama, plotting lahan untuk usaha tani sayuran dan bernilai ekonomi tinggi pada daerah Kawasan produksi pisang.

3. Introduksi Teknologi Produksi

Paket teknologi yang diintroduksikan pada demplot usahatani pisang dan usaha pengolahan dempo/sale pisang antara lain:

- Introduksi pupuk organic ramah lingkungan, untuk perbaikan sifat fisik tanah.

- Pengembangan system pertanian smart farming berbasis pisang

- Pemeliharaan tanaman sesuai kondisi lingkungan setempat dan berbasis ramah lingkungan

- Pengembangan varian aneka produk olahan pisang dan rencana pengemasan yang baik.

\section{KESIMPULAN DAN SARAN}

Berdasarkan kegiatan pengabdian yang telah dilakukan dapat disimpulkan bahwa petani pada umumnya dapat menerima dan menerapkan introduksi teknologi dan merubah tatacara budidaya yang mereka lakukan selama ini. Oleh karena itu pada introduksi usaha tani jeruk terintegrasi ini umumnya dapat menerima dan menerapkan teknologi yang diintroduksikan. Beberapa teknologi introduksi memang belum dapat sepenuhnya diterapkan karena harus merubah kultur berusaha tani seperti introduksi teknologi usaha tani tumpang pada tanaman jeruk. Hal ini disebabkan karena petani umunya khawatir jangan sampai pertumbuhan tanaman jeruk sebagai tanaman utama akan terganggu. Oleh karena itu, pembinaan dan pemberdayaan petani perlu dilakukan secara berkesinambungan, dengan priotitas pada perubahan norma dan perilaku usahatani yang dapat diterima.

\section{DAFTAR PUSTAKA}

Aurore G, Parfait B, Fahrasmane L 2009 Bananas, raw materials for making processed food products. Trends Food Sci Technol 20 78-91 10.1016/j.tifs.2008.10.003

Biro Pusat Statistik (BPS). 2010. Statistik Pertanian Indonesia. Jakarta

Balai Besar Pengkajian dan Pengembangan Teknologi Pertanian (Balitbangtan). 2008. Teknologi Budidaya Pisang. Balai Penelitian dan pengembangan Pertanian. Departemen Pertanian. 33p.

Ekesa BN, Kimiywe J, Davey M, Dhuique-Mayer C, Van den Bergh I and Blomme G. 2013. Contribution of bananas and plantains to the diet and nutrition of Musa-dependent households with preschoolers within Beni and Bukavu territories; Eastern Democratic Republic of Congo. Chapter 24. p. 202-209. In: Banana Systems in the Humid Highlands of Sub-Saharan Africa - Enhancing Resilience and Productivity CABI 
Ekesa BN, Miroir C, Blomme G, Van den Bergh I and Davey MW 2013 Retention of provitamin A carotenoids during post-harvest ripening and processing of three popular Musa cultivars in SouthWestern Uganda. Acta Horticulturae 986 319-330

Ekesa BN, Kimiywe J, Van den Bergh I, Blomme G, Dhuique-Mayer C and Davey M 2013 Content and retention of provitamin A carotenoids following ripening and local processing of four popular Musa cultivars from Eastern Democratic Republic of Congo. Sustainable Agriculture Research 2(2) 60-75

Hölscher D, Dhakshinamoorthy S, Alexandrov T, Becker M, Bretschneider T, Buerkert A,. Crecelius AC, Waele DD, Elsen A, Heckel DG, Heklau H, Hertweck C, Kai C, Knop K, Krafft C, Maddula RK, Matthäus C, Popp J, Schneider B, Schubert US, A. Sikora RA, Svatos A, Swennen RL 2014 Phenalenone-type phytoalexins mediate resistance of banana plants (Musa spp.) to the burrowing nematode Radopholus similis. PNAS 111(1) 105-110

Ekesa BN, Kimiywe J, Davey M, Dhuique-Mayer C, Van den Bergh I and Blomme G. 2013. Contribution of bananas and plantains to the diet and nutrition of Musa-dependent households with preschoolers within Beni and Bukavu territories; Eastern Democratic Republic of Congo. Chapter 24. p. 202-209. In: Banana Systems in the Humid Highlands of Sub-Saharan Africa - Enhancing Resilience and Productivity CABI

Ekesa BN, Miroir C, Blomme G, Van den Bergh I and Davey MW 2013 Retention of provitamin A carotenoids during post-harvest ripening and processing of three popular Musa cultivars in SouthWestern Uganda. Acta Horticulturae 986 319-330

Ekesa BN, Kimiywe J, Van den Bergh I, Blomme G, Dhuique-Mayer C and Davey M 2013 Content and retention of provitamin A carotenoids following ripening and local processing of four popular Musa cultivars from Eastern Democratic Republic of Congo. Sustainable Agriculture Research 2(2) 60-75

Eleazu CO and Nwosu P 2015 Nutrient and heavy metal composition of plantain (Musa paradisiaca) and banana (Musa paradisiaca) pels. J Nutr Food Sci 5(3) 1-3

Englberger L 2012 Revisiting the vitamin A fiasco: going local in Micronesia. p.126-133. In: Burlingame, B. and S. Dernini (eds.). Proceedings of Biodiversity and sustainable diets united against hunger, 3-5 November 2010. Sustainable diets and biodiversity: Directions and solutions for policy, research and action. FAO, Rome, Italy

Hölscher D, Dhakshinamoorthy S, Alexandrov T, Becker M, Bretschneider T, Buerkert A,. Crecelius AC, Waele DD, Elsen A, Heckel DG, Heklau H, Hertweck C, Kai C, Knop K, Krafft C, Maddula RK, Matthäus C, Popp J, Schneider B, Schubert US, A. Sikora RA, Svatos A, Swennen RL 2014 Phenalenone-type phytoalexins mediate resistance of banana plants (Musa spp.) to the burrowing nematode Radopholus similis. PNAS 111(1) 105-110

Kementerian Pertanian (Kementan). 2015. Statistika Produksi Hortikultura 2014. Direktorat Jenderal Hortikultura, Kementerian Pertanian Indonesia. Jakarta. 315p

Kumar GV, Kumar KA, Patel GRR and Manjappa S 2013 Determination of vitamin C in some fruits and vegetables in Davanagere city, (Karanataka) - India. Int.

Muhidin, Leomo S and Rakian TC 2015 Pisang Kate : Sumber Pangan dan Energi yang 5. Unhalu Press Kendari, Indonesia (In Indonesian)

Muhidin, Sadimantara GR, Leomo S, Rakian TC, Arma MJ and Suliartini NWS 2016 The Response of Dwarf Banana Cavendish Growth and Production Under Natural Shade. International Journal of ChemTech Research 9(12) 541-548

Nelson SC, Ploetz RC, Kepler AK 2006 Musa Species (banana and plantain). In: CR Elevitch, ed. Species Profiles for Pacific Island Agroforestry. Permanent Agricultural Resources, Holualoa, Hawai'i 
Mohr, H and P. Schoopfer. 1995. Plant physiology. Translator Gudrum and David W. Lawlor, SpringerVerlag.NY. 629p.

Samson JA 1992 Tropical Fruits. 2nd Edition. Tropical Agriculture series. Longmans, London.

Wall MM 2006 Ascorbic acid, vitamin A, and mineral composition of banana (Musa sp.) and papaya (Carica papaya) cultivars grown in Hawaii. Journal of Food Composition and Analysis 19 434-445 